\title{
Electrochemical characterization of 1,5-benzodiazepine oximes in organic solvents
}

Lina Rekovič ${ }^{1^{*}}$,

Lidija Kosychova',

Irina Bratkovskaja ${ }^{1}$,

Viltė Žukauskaité

Regina Vidžiūnaité ${ }^{1}$

${ }^{1}$ Institute of Biochemistry,

Life Sciences Center,

Vilnius University,

Sauletekio Ave. 7,

10223 Vilnius, Lithuania

${ }^{2}$ Faculty of Fundamental Sciences,

Vilnius Gediminas Technical University,

Sauletekio Ave. 11,

10223 Vilnius, Lithuania
Six novel 1,3,4,5-tetrahydro-2H-1,5-benzodiazepine oximes (1-6) were electrochemically characterized on a glassy carbon electrode by the cyclic voltammetry method in different solvents, at different $\mathrm{pH}$ values and varying the potential scan rate. The well-defined first anodic peak was observed in the solvents used and acetate buffer solution while the second oxidation peak was dimished or absent for all studied compounds. All compounds were irreversibly oxidized at positive potentials. The electron transfer process for all investigated compounds was controlled by diffusion. Oxidation potentials were dependent on the molecular structures of investigated compounds as well as on the solvent nature.

Keywords: 1,3,4,5-tetrahydro-2H-1,5-benzodiazepine oximes, electrochemistry, cyclic voltammetry, organic solvents

\section{INTRODUCTION}

Benzodiazepines (BZD) and their polycyclic derivatives are pharmacologically active compounds that have extensive applications in medicine as psychoactive drugs [1]. They are widely used as analgesics, hypnotics, sedatives and antidepressants as well as anti-inflammatory agents [1, 2. 1]. 1,4 and 1,5$\mathrm{BZD}$ are reported to possess distinctive pharmacological effects. 1,5-BZD has received a great attention of medicinal research and a lower incidence of side effects has been reported for new derivatives with enhanced pharmacological activities [3]. 1,4 and 1,5-BZD are used in organic synthesis as precursors of fused polycyclic benzodiazepine deriva-

*Corresponding author. Email: lina.rekovic@protonmail.com tives [4]. In addition, various diazepines have been reported as fungicidal and herbicidal agents [5].

Due to an easily reducible azomethine moiety and a number of other substituted electrochemically active groups, such as nitro, $\mathrm{N}$-oxide and carbonyl groups, BZD are often characterized and detected in biological, pharmaceutical, biomedical and forensic investigations by electrochemical methods [6]. However, research has been focused mainly in the electrochemical cathodic behaviour of the 1,4-BZD, while data related to 1,5-BZD either cathodic or anodic behaviour is limited.

Oximes $(=\mathrm{N}-\mathrm{OH})$ are widely used in organic synthesis as intermediates for the preparation of amides via the Beckmann rearrangement and for conversion of noncarbonyl compounds to the carbonyl derivatives [8] 8. Moreover, oximes belong 
to a broad class of N-hydroxy compounds which are well-known as redox-active mediators in biocatalytic systems [9].

Electrochemistry allows one to mimic biological oxidation processes and better understand the redox mechanisms of many biologically significant molecules and pharmaceutically active compounds [10]. Thus electrochemical oxidation of 1,5-BZD may provide better understanding of 1,5BZD metabolism pathways in vivo.

Six novel 1,3,4,5-tetrahydro- $2 H$-1,5-benzodiazepine oximes have been synthesized and described earlier [11]. Structures of investigated oximes 1-6 are very similar, they differ only by the methyl group position and the number in the diazepine ring (2-3, 4-6). Compounds 4-6 contain a meth$\mathrm{yl}$ group in the diazepine ring at the 5 th nitrogen atom, whereas 1-3 compounds do not.

In this study we have performed the electrochemical characterisation of new compounds by the cyclic voltammetry method. Cyclic voltammograms were recorded for all the synthesized compounds in different solvents, at different $\mathrm{pH}$ values and varying the potential scan rate. Glassy carbon electrode was used as a working electrode due to its wide potential range, chemical inertness, impermeability to gases and extremely low porosity [2].

\section{EXPERIMENTAL}

\section{Reagents}

Anhydrous acetonitrile (AN), 96\% ethanol (EtOH) and anhydrous dimethyl sulfoxide (DMSO) were received from Sigma Chemical Co (USA). Tetraethylammonium tetrafluorborate (TEA-TFB) was received from Aldrich-Chemie (Steinhem) and was used as a supporting electrolyte in organic solutions.

Sodium acetate, acetic acid, potassium phosphate, potassium hydroxide and other reagents were of analytical grade and were received from Sigma. Britton-Robinson buffer (BRB-I) solutions were obtained by titrating a mixture of $20 \mathrm{mM}$ $\mathrm{H}_{3} \mathrm{BO}_{3}, 20 \mathrm{mM} \mathrm{KH}_{2} \mathrm{PO}_{4}$ and $20 \mathrm{mM} \mathrm{CH}_{3} \mathrm{COOH}$ with $0.3 \mathrm{M} \mathrm{NaOH}$ until necessary $\mathrm{pH}$ [12]. The buffer solutions were prepared by using double distilled water.

The novel 1,3,4,5-tetrahydro-2H-1,5-benzodiazepine oximes (1-6) (Fig. 1) were synthesized by heating 1,5-benzodiazepinthiones, sodium acetate and hydroxylamine hydrochloride in anhydrous ethanol as was previously described by Kosychova et al. [11].

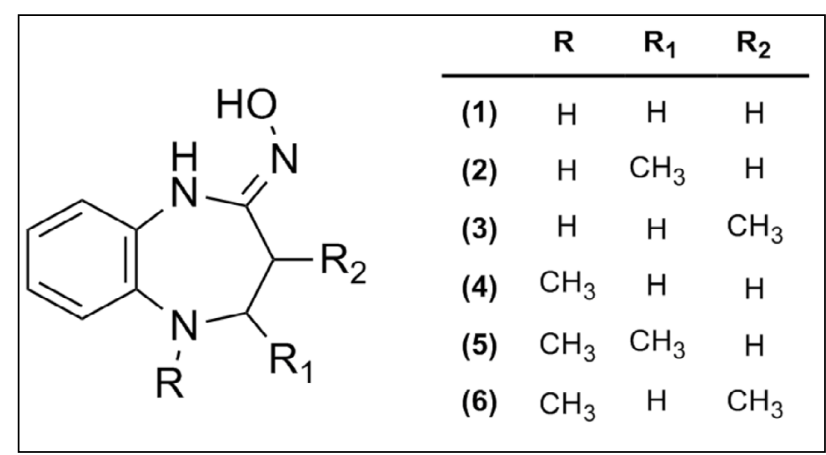

Fig. 1. Chemical structures of 1,3,4,5-tetrahydro-2H-1,5-benzodiazepine oximes (1-6) researched in this work

\section{Apparatus}

Electrochemical experiments were performed with a Series $\mathrm{G}^{\mathrm{m}} 750$ Potentiostat/Galvanostat/ZRA from Gamry Instruments, Inc. (Warminster, PA, USA), controlled by the dedicated PHE200 ${ }^{\text {mix }}$ software. All experiments were carried out in a three-electrode glass cell using an $\mathrm{Ag} / \mathrm{AgCl}(3 \mathrm{M} \mathrm{KCl})$ electrode as a reference electrode ( $210 \mathrm{mV}$ vs NHE), glassy carbon (BASi MF-2012, $3 \mathrm{~mm}$ diameter, USA) as a working electrode and a Pt wire (diameter $0.2 \mathrm{~mm}$, length $4 \mathrm{~cm}$ ) as a counter electrode.

The glassy carbon electrode was freshly polished with aluminium oxide, treated ultrasonically in water for $10 \mathrm{~min}$ and washed with deionized water after every measurement.

\section{Work solutions}

Cyclic voltammetry (CV) measurements were performed at room temperature in AN, DMSO, 96\% ethanol. $50 \mathrm{mM}$ TEA-TFB was used as a supporting electrolyte in organic solutions. The concentration of compounds was about $1.0 \mathrm{mM}$.

The dependences of 1-6 compounds oxidation potentials on the buffer solution $\mathrm{pH}$ were determined by using Britton-Robinson buffer solutions with different $\mathrm{pH}$ in the interval 3.5-11.5, scan rate $0.1 \mathrm{~V} / \mathrm{s}$.

\section{Cyclic voltammetry}

The electrode potential was varied between 0 and $1 \mathrm{~V}$. Cyclic voltammograms $(\mathrm{CV})$ were registered at several scan rates: $0.025,0.05,0.1,0.25$ and $0.5 \mathrm{~V} / \mathrm{s}$. 
The slope of the oxidation current vs the square root of the potential scan rate was used for calculating the diffusion coefficients by using the Randles-Sevcik equation (Eq. 1) [13]:

$$
I_{p}=0.4463 n F A c \cdot\left(\frac{n F w D}{R T}\right)^{1 / 2} \text {. }
$$

Here $I_{p}$ is the peak current value, $n$ is the number of electrons transferred in the redox event, $F$ is the Faraday constant, $A$ is the geometric surface area of the working electrode in $\mathrm{cm}^{2}, c$ is the bulk concentration of the electroactive species in $\mathrm{mol} /$ $\mathrm{cm}^{3}, R$ is the universal gas constant, $T$ is the temperature in Kelvin, $D$ is the diffusion coefficient in $\mathrm{cm}^{2} / \mathrm{s}$ of the electroactive species and $w$ is the potential scan rate in $\mathrm{V} / \mathrm{s}$.

\section{RESULTS AND DISCUSSION}

\section{$\mathrm{CV}$ in different solvents}

The cyclic voltammetry method was used to investigate the electrochemical oxidation of 1-6 compounds in different solvents. Figure 2 shows the voltammograms of the studied compounds in the acetate buffer solution $\mathrm{pH} 5.5$ (a) and ethanol (b) (potential scan interval 0-1 V).

During the electrochemical oxidation of compounds 1-6 in the acetate buffer solution on scanning in the anodic direction two oxidation peaks were observed in the 0 and $1 \mathrm{~V}$ region, while in the reverse sweep symmetrical reduction peaks were absent, which indicated that the oxidation process was irreversible (Fig. 2a). Conversely, the oxidation of 1-6 compounds in ethanol on scanning in the positive direction resulted in only one oxidation peak, while in the cathodic direction reduction peaks were absent as in the acetate buffer (Fig. 2b).

Oxidation potentials for compounds 1-3 in ethanol were observed at $+0.66-0.72 \mathrm{~V}$ interval, while for compounds $\mathbf{4}$ and $\mathbf{6}$ they were registered at higher potential values $+0.73-0.92 \mathrm{~V}$, e.g. for compound 5 at $+0.84-0.92 \mathrm{~V}$. Similar results for the oxidation potentials of 1,5-benzodiazepine oximes are obtained in DMSO and AN, but in AN they were somewhat smaller than in DMSO (Fig. 3).

In the acetate buffer solution all investigated compounds were oxidized at lower potentials $(+0.42-0.57 \mathrm{~V})$ in comparison to oxidation potentials in other solvents used (EtOH, DMSO and AN) (Table 1). Also it was noticed that CV of compound 3 (Fig. $3 \mathrm{c}$ ) in AN differed from that of compounds $\mathbf{1}$ and $\mathbf{2}$, in this case two oxidation peaks at $+0.55-0.62 \mathrm{~V}$ and $+0.80-0.87 \mathrm{~V}$ were observed. For compounds 4 and $\mathbf{6}$ two poorly defined oxidation peaks were also registered, while for compound $\mathbf{5}$ only one peak was observed (Fig. 3d-f, Table 1).

From the data presented in Table 1, it can be concluded that compounds 1-3 in ethanol, acetate buffer and AN are oxidized at lower potentials than compounds 4-6, i.e. in the latter case oxidation peaks shift to higher potentials.

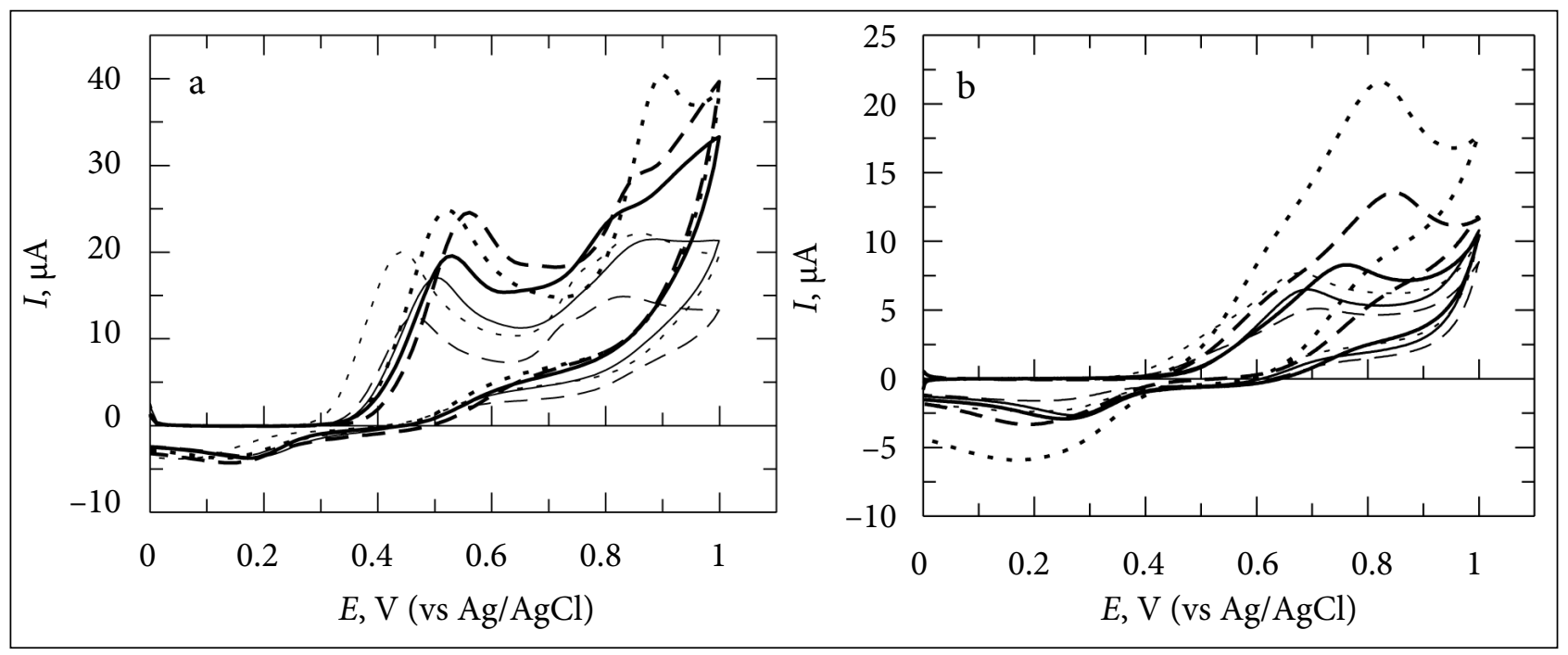

Fig. 2. Cyclic voltammograms of $\mathbf{1 - 6}$ compounds (1 mM) in (a) acetate buffer (50 mM pH 5.5) solutions and (b) ethanol; scan rate $0.1 \mathrm{~V} / \mathrm{s}$; $1(-), 2(---), 3(\cdots .),. 4(-), 5(-), 6(\cdots .$. 


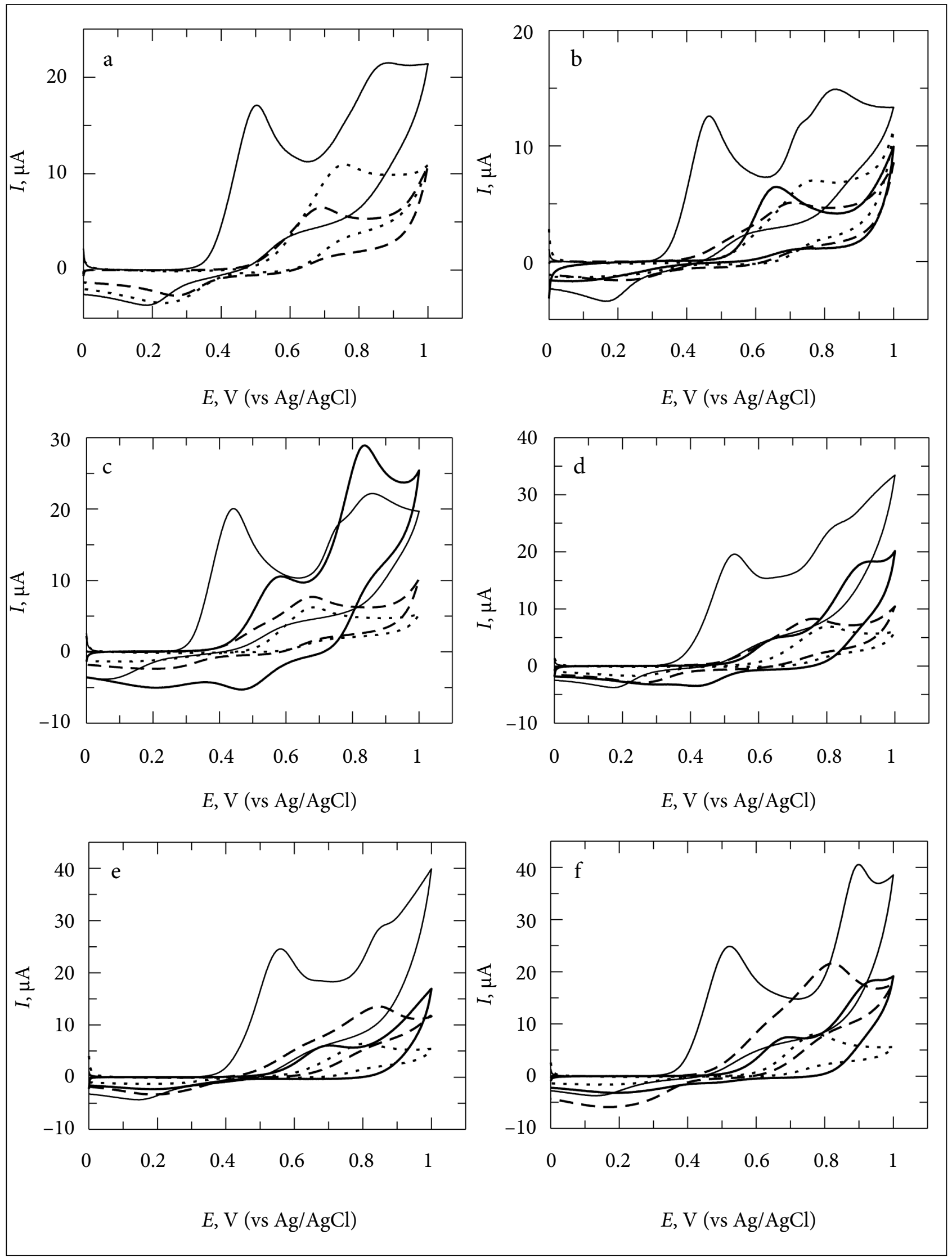

Fig. 3. Cyclic voltammograms of 1-6 compounds (1 mM) (a-f) in different solvents: acetate buffer ( $50 \mathrm{mM} \mathrm{pH} 5.5)$ solution (一), ethanol (- ), DMSO (....), acetonitrile $(-)$; scan rate $0.1 \mathrm{~V} / \mathrm{s}$ 
Table 1. Oxidation potential values ( $\varphi 1_{\max }$ and $\varphi 2_{\max }$ ) of compounds 1-6 in various solvents

\begin{tabular}{|c|c|c|c|c|c|c|}
\hline \multirow{2}{*}{ Compound } & \multirow{2}{*}{$\begin{array}{c}\text { Ethanol } \\
\varphi 1_{\max }\end{array}$} & \multicolumn{2}{|c|}{ Acetate buffer } & \multirow{2}{*}{$\begin{array}{l}\text { DMSO } \\
\varphi 1_{\text {max }}\end{array}$} & \multicolumn{2}{|c|}{ AN } \\
\hline & & $\varphi 1_{\text {max }}$ & $\varphi 2_{\max }$ & & $\varphi 1_{\text {max }}$ & $\varphi 2_{\text {max }}$ \\
\hline 1 & $0.66-0.71$ & $0.46-0.50$ & $0.83-0.85$ & $0.74-0.77$ & $-^{*}$ & $-^{*}$ \\
\hline 2 & $0.68-0.72$ & $0.43-0.45$ & $0.81-0.82$ & $0.74-0.78$ & $0.64-0.67$ & - \\
\hline 3 & $0.68-0.72$ & $0.42-0.46$ & $0.81-0.84$ & $0.67-0.71$ & $0.55-0.62$ & $0.80-0.87$ \\
\hline 4 & $0.73-0.78$ & $0.50-0.55$ & $0.88-0.92$ & $0.78-0.83$ & $0.66-0.68^{*}$ & $0.88-0.92^{* *}$ \\
\hline 5 & $0.84-0.92$ & $0.54-0.57$ & $0.83-0.87$ & $0.75-0.82$ & $0.66-0.74$ & - \\
\hline 6 & $0.74-0.84$ & $0.50-0.55$ & $0.85-0.88$ & $0.74-0.84$ & $0.67-0.72$ & $0.93-0.95^{* *}$ \\
\hline
\end{tabular}

* Data not available due to poor solubility of compound 1 in AN.

** Poorly defined oxidation peaks.

\section{Scan rate study}

The effect of the voltage scan rate on the oxidation peak current of compounds 1-6 was studied in order to distinguish whether adsorption or dif- fusion is controlling the electron transfer process (Fig. 4). CVs were recorded in the range from 0.025 to $0.5 \mathrm{~V} / \mathrm{s}$ in organic solvents and in the acetate buffer, $\mathrm{pH} 5.5$, containing $1 \mathrm{mM}$ of the investigated

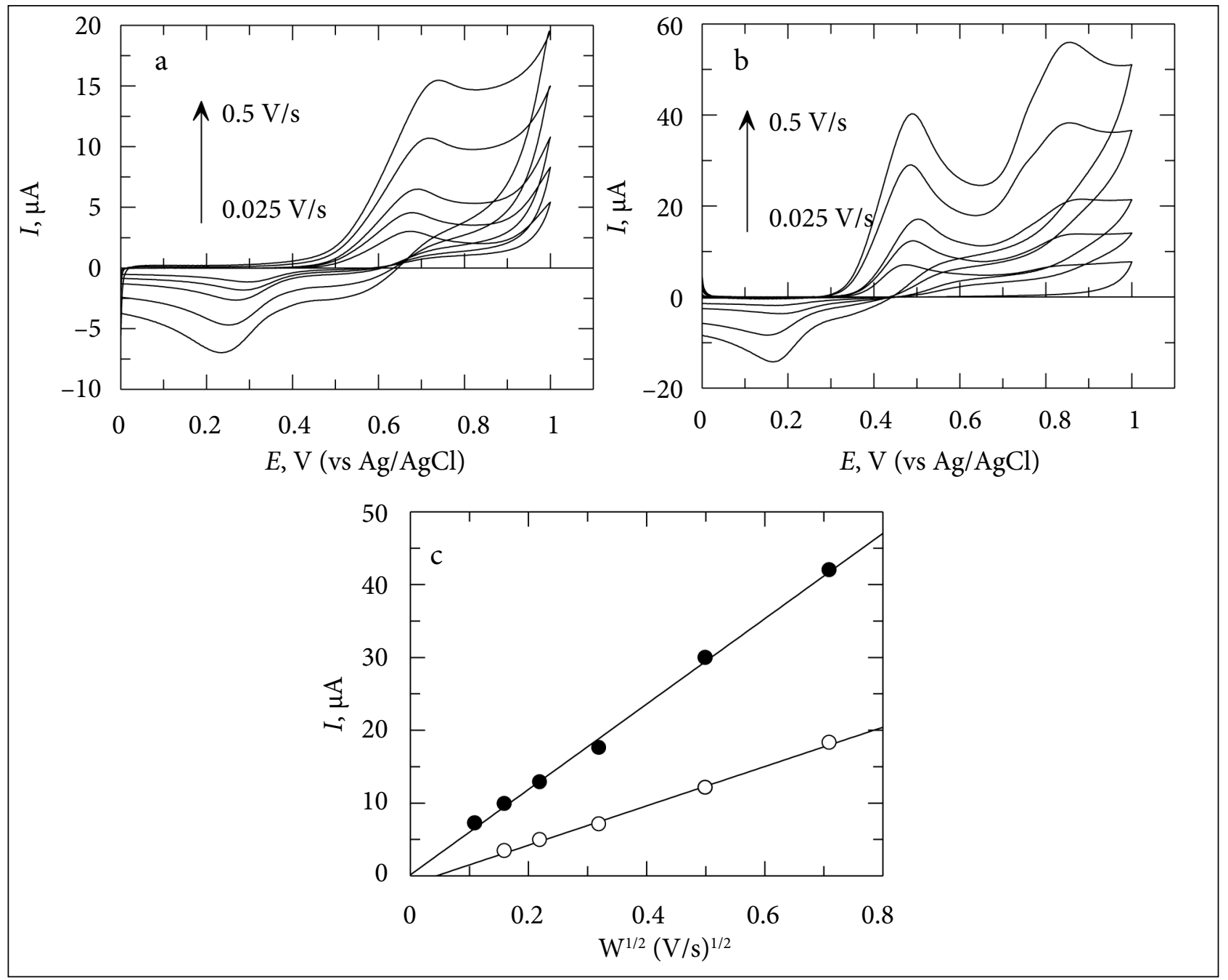

Fig. 4. Cyclic voltammograms for 1 compound ( $1 \mathrm{mM}$ ) in (a) ethanol and (b) acetate buffer ( $50 \mathrm{mM}$ pH 5.5) solution at various scan rates ( 0.025 to $0.5 \mathrm{~V} / \mathrm{s}) ;(\mathrm{c})$ the dependence of the oxidation peak current on the square root of the scan rate $\left(w^{1 / 2}\right)$ for compound $\mathbf{1}$ in ethanol $(0)$ and acetate buffer $(\bullet)$ 
compound and always using a freshly polished electrode surface.

As is evident from Fig. 4, on increasing the voltage scan rate the oxidation peak current increases and the shift of the peak maxima is observed, which is characteristic of irreversible processes [14].

The influence of the square root of the voltage scan rate $\left(w^{1 / 2}\right)$ on the oxidation peak current showed a linear relationship within the whole range studied (Fig. 5) and the slope varied in the interval $0.42-0.56$, which is typical of a diffusion controlled oxidation process, and the corresponding value is presented in literature for 1,5BZD derivatives [2]. Similar dependences were determined for all synthesized oximes in all solvents used.

Diffusion coefficients of 1-6 compounds were calculated using the Randles-Sevcik equation. The obtained values were in the $10^{-6} \mathrm{~cm}^{2} \mathrm{~s}^{-1}$ range. Table 2 summarizes the obtained values.

The obtained values in ethanol were smallest. Conversely, in DMSO and AN they were largest. In the acetate buffer solution they were in the range (5.7-19.6) $\times 10^{-6}$. In all solvents used for 1 compound the diffusion coefficient was the smallest, while for other compounds values were very similar.

\section{pH dependency by CV}

The $\mathrm{pH}$ is an important factor in the electrochemical behaviour of organic compounds, because protons are always involved in electrochemical reactions. The influence of $\mathrm{pH}$ on the electrochemical oxidation of compounds 1-6 was studied by using
Table 2. Diffusion coefficients of 1-6 compounds in various solvents

\begin{tabular}{|c|c|c|c|c|}
\hline \multirow{2}{*}{ Compound } & \multicolumn{4}{|c|}{$\mathrm{D} \times 10^{-6}, \mathrm{~cm}^{2} \mathrm{~s}^{-1}$} \\
\hline & Ethanol & Acetate buffer & DMSO & AN \\
\hline 1 & 1.7 & 5.7 & 30.1 & - \\
\hline 2 & 3.8 & 7.1 & 23.5 & 21.9 \\
\hline 3 & 5.2 & 11.8 & 17.4 & 24.8 \\
\hline 4 & 3.3 & 19.6 & 22.6 & $-^{*}$ \\
\hline 5 & 4.2 & 16.8 & 16.5 & 29.0 \\
\hline 6 & 4.9 & 18.9 & 18.5 & $-{ }^{*}$ \\
\hline
\end{tabular}

* Data not available due to the pooly defined peak.

cyclic voltammetry over a wide $\mathrm{pH}$ range between 3.5 and 12.0. The CV responses were recorded in $1.0 \mathrm{mM}$ solutions of the investigated compounds at different Britton-Robinson buffer solution $\mathrm{pH}$ and the constant voltage scan rate $0.1 \mathrm{mV} / \mathrm{s}$.

Cyclic voltammograms for $\mathbf{1}$ compound at the buffer solution $\mathrm{pH}$ between 3.5 and 9.0 are presented in Fig. 6. It clearly illustrates that the peak potential shifts with $\mathrm{pH}$, thus indicating the involvement of protons in the oxidation process. An identical behaviour was exhibited by all investigated compounds. In addition, similar observations were reported in the literature on the oxidation of benzodiazepine derivative flunitrazepam [15].

It was determined that at more basic buffer solution $\mathrm{pH}$ oximes 1-6 were oxidized at significantly lower potential values than in acidic media, e.g. at the most acidic buffer solution $\mathrm{pH}$ (3.5) the first oxidation reaction of oxime 1 appeared at $0.5 \mathrm{~V}$, the second one at $0.88 \mathrm{~V}$, whereas at the most basic $\mathrm{pH}(9.0)$ at $0.3 \mathrm{~V}$ and $0.6 \mathrm{~V}$, respectively.

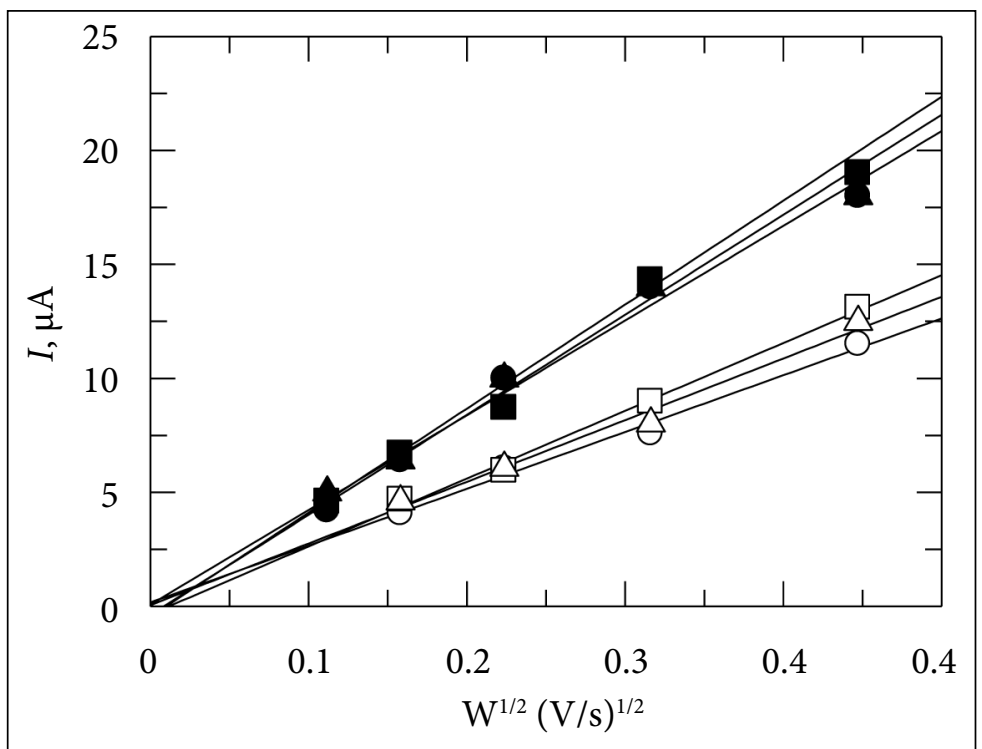

Fig. 5. The dependence of the oxidation peak current on the square root of the voltage scan rate $\left(W^{1 / 2}\right)$ for compounds 1-6 in the BRB-I buffer solution (pH 5.5); 1 (०), $2(\square), 3(\Delta), 4(\bullet), 5(\mathbf{\square}), 6(\mathbf{\Delta})$ 


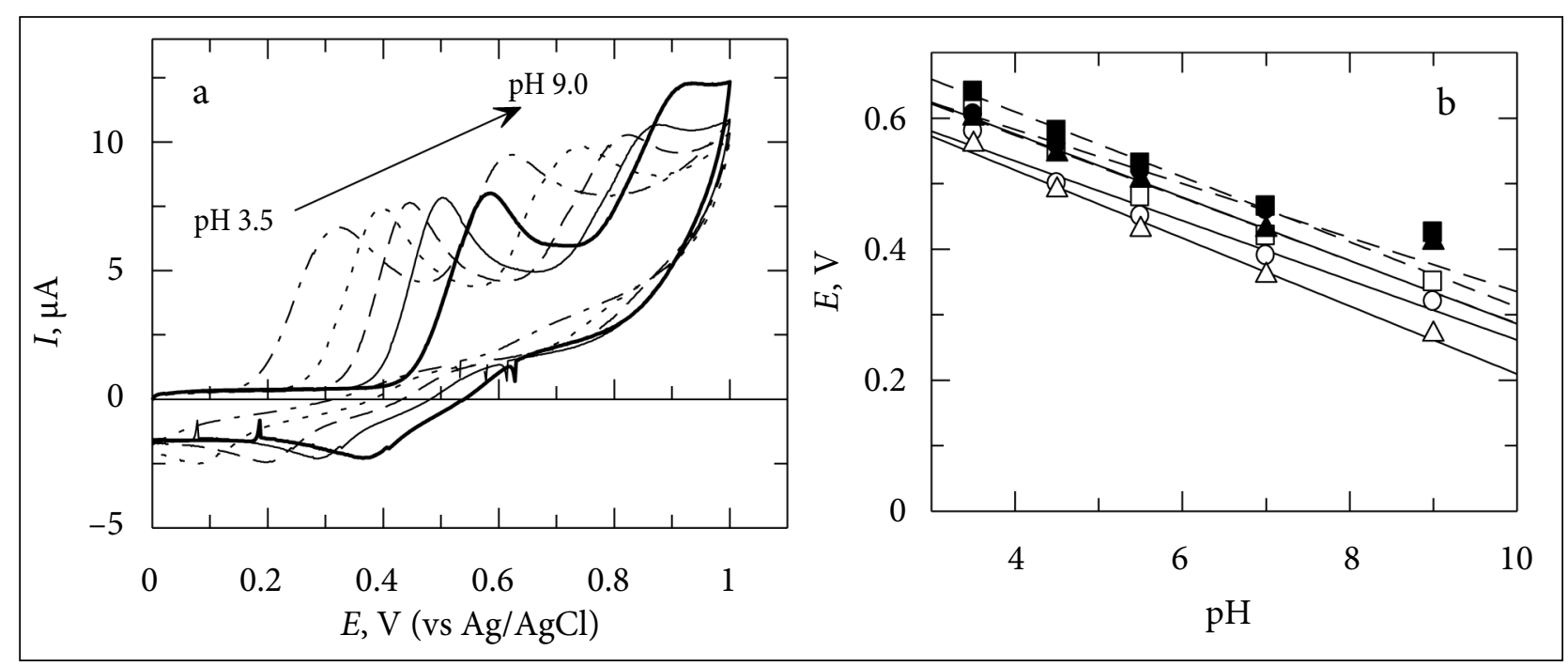

Fig. 6. (a) Cyclic voltammograms for 1 compound (1 mM) at different BRB-I buffer solution pH, scan rate $0.1 \mathrm{~V} / \mathrm{s}$; pH 3.5 (一), pH 4.5 (一), pH $5.5(---)$, pH 7.0 (.....), pH $9.0(-\cdots-.-)$; (b) the dependence of the first oxidation peak potential of 1-6 compounds on solution pH; 1 (O), $2(\square), 3(\Delta), 4(\bullet), 5(\mathbf{\square}), 6(\mathbf{\Delta})$

The oxidation peak potentials of all investigated compounds 1-6 were observed to shift to more negative potentials with increasing $\mathrm{pH}$ with the plot of the peak potential against $\mathrm{pH}$ exhibiting a linear relationship over the $\mathrm{pH}$ range of 3.5-9.0. The linear relationships between the first oxidation reaction potential values and media $\mathrm{pH}$ were determined for all investigated compounds and are presented in Fig. $6 \mathrm{~b}$.

The calculated gradients from the linear part of $E_{p}$ vs $\mathrm{pH}$ dependencies are given in Table 3 . As it is known from the literature, the slope from the linear part provides an insight on the number of electrons and protons transferred in the electrochemical process in the case when the process is fully revers-

Table 3. The slopes of the dependences of the first and the second oxidation peak potentials of 1-6 compounds on solution pH between 3.5 to $9.0 \mathrm{pH}$ range

\begin{tabular}{ccc}
\hline Compound & $\begin{array}{c}\text { The first oxidation } \\
\text { peak, } \mathbf{m V} / \mathbf{p H}\end{array}$ & $\begin{array}{c}\text { The second oxidation } \\
\text { peak, } \mathbf{m V} / \mathbf{p H}\end{array}$ \\
\hline 1 & $54 \pm 2$ & $51 \pm 1$ \\
\hline 2 & $54 \pm 3$ & $53 \pm 1$ \\
\hline 3 & $54 \pm 1$ & $54 \pm 1$ \\
\hline 4 & $34 \pm 3$ & $-{ }^{*}$ \\
\hline 5 & $39 \pm 5$ & $-{ }^{*}$ \\
\hline 6 & $35 \pm 5$ & $-{ }^{*}$ \\
\hline
\end{tabular}

* Data not available due to the pooly defined peak of the second oxidation reaction. ible. The slope around $60 \mathrm{mV} / \mathrm{pH}$ is characteristic of the same number of electron and proton transfer processes and $30 \mathrm{mV} / \mathrm{pH}$ is obtained for a twoelectron and one-proton process [14].

As it can be seen from the data presented in Table 3, the slope values are very close to the anticipated Nernstian values. Though, in the case of analysed compounds (1-6) further studies are necessary in order to clarify whether the oxidation reaction is fully irreversible or quasi-reversible and propose a possible redox mechanism.

However, from the data obtained it can be concluded that despite the insignificant differences in the molecular structures of analysed compounds, the first electrochemical oxidation reaction of 1-3 and 4-6 compounds corresponds to a different number of electrons and protons transferred.

It is necessary to mention that for 1-3 compounds in the $\mathrm{pH}$ region under 4.0 and over 9.0 the deviation from linearity was observed, which can be associated with the protonation and deprotonation of the target molecule. As was previously determined by the spectrofluorimetric method, the pKa of the studied 1-3 compounds is $4.5,4.6$, 4.5 and that of 4-6 compounds is 4.2, 4.4, 4.2, respectively [16. From the literature it is also known that the pKa value for dissociation of the $\mathrm{N}-\mathrm{OH}$ proton in oximes ranges between 10 and 13 in water [17], thus the deviation from linearity may be attributed to the deprotonation of the aforementioned $\mathrm{N}-\mathrm{OH}$ group. 


\section{CONCLUSIONS}

Six novel 1,3,4,5-tetrahydro-2H-1,5-benzodiazepine oximes (1-6) were electrochemically characterized on a glassy carbon electrode by the cyclic voltammetry method in different solvents, at different $\mathrm{pH}$ values and varying the potential scan rate. All compounds were irreversibly oxidized at positive potentials. The number of the oxidation reactions registered for 1-6 compounds in the studied potential range depended on the solvent nature as well as on the molecular structure. Noticable differences in oxidation potentials appeared for compounds containing a methyl group in the diazepine ring at the 5th nitrogen atom (4-6). The latter were oxidized at higher potentials in all solvents used in comparison to 1-3 oximes. The electron transfer process for all investigated compounds was controlled by diffusion. The investigation of the influence of $\mathrm{pH}$ on the electrochemical behaviour of compounds 1-6 showed the involvement of protons in the oxidation process. It was determined that at more basic buffer solution $\mathrm{pH}$ the oxidation potentials of oximes 1-6 were significantly shifted to lower potentials in comparison to acidic media. The calculated gradients from the linear part of $E_{p}$ vs $\mathrm{pH}$ dependencies showed that the first electrochemical oxidation reaction of 1-3 and 4-6 compounds corresponds to a different number of electrons and protons transferred.

Received 6 October 2018 Accepted 12 October 2018

\section{References}

1. P. Aastha, K. Navneet, A. Anshu, S. Pratima, K. Dharma, Res. J. Chem. Sci., 3, 90 (2013).

2. P. Jara-Ulloa, S. Catalan-Caro, C. A. Escobar, J. Chil. Chem. Soc., 59, 2520 (2014).

3. O. Mazimba, T. C. Molefe, Int. J. Chem. Stud., 3, 46, (2015).

4. L. Kosychova, R. Vidžiūnaitè, G. Mikulskienė, I. Bratkovskaja, R. Jančienė, Arkivoc (v), 71, (2015).
5. S. S. Kumar, P. K. Helen, S. Arulmurugan, B. R. Venkatraman, Mini Rev. Org. Chem., 9, 285 (2012).

6. K. Honeychurch, J. P. Hart, Insciences J., 4, 1 (2014).

7. X.-T. Zhou, Q.-L. Yuan, H.-B. Ji, Tetrahedron Lett., 51, 613 (2010).

8. N. C. Ganguly, S. Nayek, S. K. Barik, Synth. Commun., 39, 4053 (2009).

9. F. Xu, H. J. Deussen, B. Lopez, L. Lam, K. Li, Eur. J. Biochem., 268, 4169 (2001).

10. H. Y. Aboul-Enein, Chromatographia, 75, 811 (2012).

11. L. Kosychova, Z. Stumbrevičiūtè, L. Plečkaitienė, Z. Staniulytė, B. Puodžiūnaitè, Chemija, 17, 21 (2006).

12. A. M. Michalowska-Kaczmarczyk, T. Michalowski, J. Solution Chem., 44, 1256 (2015).

13. T. Lanez, N. Salah, Int. J. Chem. Stud., 1, 28 (2013).

14. D. Brownson, C. Banks, The Handbook of Graphene Electrochemistry, Springer-Verlag London (2014).

15. E. Garcia-Gutierrez, C. Lledo-Fernandez, Chemosensors, 1, 68 (2013).

16. L. Rekovic, L. Kosychova, I. Bratkovskaja, R. Vidžiūnaitè, J. Serb. Chem. Soc. (2018). Manuscript submitted for publication.

17. S. B. King, in: P. G. Wang, T. B. Cai, N. Taniguchi (eds.), Nitric Oxide Donors, p. 177, WileyVCH Verlag GmbH \& Co. KGaA (2005).

Lina Rekovič, Lidija Kosychova, Irina Bratkovskaja, Viltė Žukauskaitė, Regina Vidžiūnaitė

\section{1,5-BENZODIAZEPINŲ OKSIMŲ ELEKTROCHEMINIS CHARAKTERIZAVIMAS ORGANINIUOSE TIRPIKLIUOSE}

Santrauka

Šeši 1,3,4,5-tetrahidro-2H-1,5-benzodiazepinų oksimai (1-6) elektrochemiškai charakterizuoti ciklinès voltamperometrijos metodu naudojant stiklo anglies elektrodą ivairiuose tirpikliuose esant skirtingoms $\mathrm{pH}$ reikšmèms ir keičiant potencialo skleidimo greitị. Ryški pirma anodinè smaile buvo stebima tirtuose tirpikliuose ir acetatiniame buferyje, kai antroji tirtų junginių oksidacine smailè nebuvo išreikšta arba nebuvo stebima. Visi junginiai, esant teigiamiems potencialams, oksiduojami negrịžtamai. Tirtų junginių elektronų pernašos procesas buvo kontroliuojamas difuzijos. Oksidacinis potencialas priklausè tiek nuo tirtų junginių molekulių struktūros, tiek nuo tirpiklio prigimties. 